\title{
NATURAL HISTORY OF THE TERRESTRIAL GREEN ALGA, PRASIOLA CRISPA (TREBOUXIOPHYCEAE), AND ASSOCIATED HERRING GULLS ON BRIER ISLAND, NOVA SCOTIA
}

\author{
DAVID J. GARBARY ${ }^{1}$ AND NICHOLAS M. HILL ${ }^{1,2}$ \\ ${ }^{1}$ Jack McLachlan Laboratory of Aquatic Plant Resources, \\ Department of Biology, St. Francis Xavier University, \\ Antigonish, NS B2G 2W5 \\ ${ }^{2}$ Fern Hill Institute of Plant Conservation, \\ South Berwick, NS BOP 1EO
}

\begin{abstract}
The local distribution of Prasiola crispa is reported for the first time in Nova Scotia. It was common on emergent basalt outcrops in a coastal wetland on the Bay of Fundy shores of Brier Island. The alga was present on 19 of 102 basalt outcrops in one of the breeding colonies of the Herring Gull, Larus argentatus, and was only associated with basalt outcrops with gull feces. Patches of $P$. crispa were typically associated with the north facing slopes of the rock or were present in depressions or parts of the rock shaded by adjacent vegetation. At Western Light, the gulls are both facilitating the presence of P. crispa and acting as ecosystem engineers by nesting in the adjoining vegetation where their trampling and nutrient inputs are modifying the surrounding wetland ecosystem.
\end{abstract}

Key Words: Brier Island, ecological engineers, Herring gulls, Prasiola crispa

\section{INTRODUCTION}

The genus Prasiola comprises 35 specific and infraspecific taxa occurring in marine, freshwater and terrestrial communities (Guiry and Guiry 2016). The genus is cosmopolitan, occurring on all continents and from arctic to tropical habitats (Rindi 2007). Most species consist of monostromatic blades typically less than $1 \mathrm{~cm}$, although 
some species may be $10 \mathrm{~cm}$ or longer, and some developmental forms may be uniseriate or ribbon-like.

Prasiola crispa (Lightfoot) Kützing is a Holarctic species and associated with arctic to temperate maritime conditions in both the Northern and Southern Hemispheres. The species is well known and extensively collected from Greenland and many coastal regions of western Europe through to the White Sea (e.g., Rindi 2007, Garbary and Tarakhoskaya 2013). However, the species has been poorly documented in eastern North America with Canadian historical records limited to Newfoundland and Quebec (Collins 1909, South 1973, Gauthier et al. 1980), and there is little information on its ecology. Recently Mathieson and Dawes (2017) included Nova Scotia as part of the distribution, without providing specific locales.

Prasiola crispa can be easily confused with the more marine species, P. stipitata Suhr ex Jessen, which is common along the Atlantic and Bay of Fundy shores of Nova Scotia and throughout much of northeastern North America (Taylor 1957, Sears 1998, Mathieson and Dawes 2017). Prasiola stipitata is common in the splash zone of exposed rocky shores where gulls deposit their droppings. On Digby Neck and associated islands (including Brier Island) and around the Bay of Fundy, the species is common (Edelstein et al. 1969, Wilson 1979, South et al. 1988, Kang et al. 2013), and in winter and spring may cover many square meters (Kang et al. 2013). During summer the populations are much smaller. One extensive population of P. stipitata was found near North Light on Brier Island in mid-August in the splash zone associated with bird droppings, crab remains, and the lichen Xanthoria sp. (Garbary, unpublished observations). There are other terrestrial species of Prasiola such as. P. calophylla (Carmichael ex Greville) Kützing, and P. furfuracea (Mertens ex Hornemann) Kützing, that occur in terrestrial coastal habitats around the North Atlantic and Arctic Oceans (e.g., Rindi 2007, Garbary and Tarakhovskaya 2013),

In the present paper, we report results of a survey on Brier Island for the occurrence of Prasiola crispa, a boreal/arctic species of this algal genus, where cold water upwelling of the Bay of Fundy creates boreal conditions (Brown and Gaskin 1988). Prasiola crispa was discovered in 2016 on basalt outcrops of the island in a nesting colony of the Herring Gull, Larus argentatus (Pontopiddan 1763). 


\section{MATERIALS AND METHODS}

\section{Study Area}

Brier Island, Nova Scotia $\left(44^{\circ} 15^{\prime} \mathrm{N} 66^{\circ} 22^{\prime} \mathrm{W}\right.$, Fig 1), has a boreal climate and vegetation largely comprised of scrub forest of Picea mariana (Mill) BSP(Black Spruce), with extensive wetlands of bogs and fens through to coastal heaths. The island is home to the rare flowering plant, Geum peckii Pursh (Paterson \& Snyder 1999, Blaney 2010, Garbary and Hill 2014). The principal population of G. peckii is in Big Meadow Bog $\left(44^{\circ} 15.17^{\prime} \mathrm{N}, 66^{\circ} 21.5^{\prime} \mathrm{W}\right)$, and it is threatened by an estimated 6000 Herring Gulls (Toms 2015), the second largest nesting colony east of the Great lakes (Cotter et al.2012). A second breeding colony of Herring Gulls occurs at Western Light (44'14.7' $\mathrm{N}$, $66^{\circ} 23.5^{\prime} \mathrm{W}$, Fig 2), and a third colony occurs on shoreline cliffs near the eastern tip of the island at Big Cove $\left(44^{\circ} 15.8^{\prime} \mathrm{N}, 66^{\circ} 20.66^{\prime} \mathrm{W}\right)$. The small community of Westport (population ca. 400) thrives on diverse commercial fishing activities and tourism.

The area occupied by the gulls includes ca. $20 \%$ of a large wetlandheath system that has been partially drained by road development and ditching of the gravel road to the lighthouse. The Western Light area differs from the larger wetland of Big Meadow Bog in that the former has numerous outcrops of the basalt bedrock in an area ca. $130,000 \mathrm{~m}^{2}$ where the birds nest and use the rock outcrops and clumps of Black spruce as perches. The gulls deposit considerable fecal matter on the rocks and throughout the wetland community. We initially investigated this site to collect regurgitated gull feeding pellets for comparison of feeding activity with the gulls in Big Meadow Bog (Hill and Garbary, unpublished data). As part of this survey, populations of an epilithic, green foliose alga were noted that were likely members of the genus Prasiola.

\section{Field Methods and Observations}

Numerous walks through Big Meadow Bog occurred from 2014 onward by both authors without observing any colonies of Prasiola. The very-large gull nesting colony in Big Meadow Bog had neither rock outcrops nor Prasiola. A single examination of the nesting colony near the eastern end of the island at Big Cove (Fig 1) had no apparent Prasiola, despite extensive basalt cliffs.

The area at Western Light where the gulls were nesting in the vegetation was studied during three random walks through the 


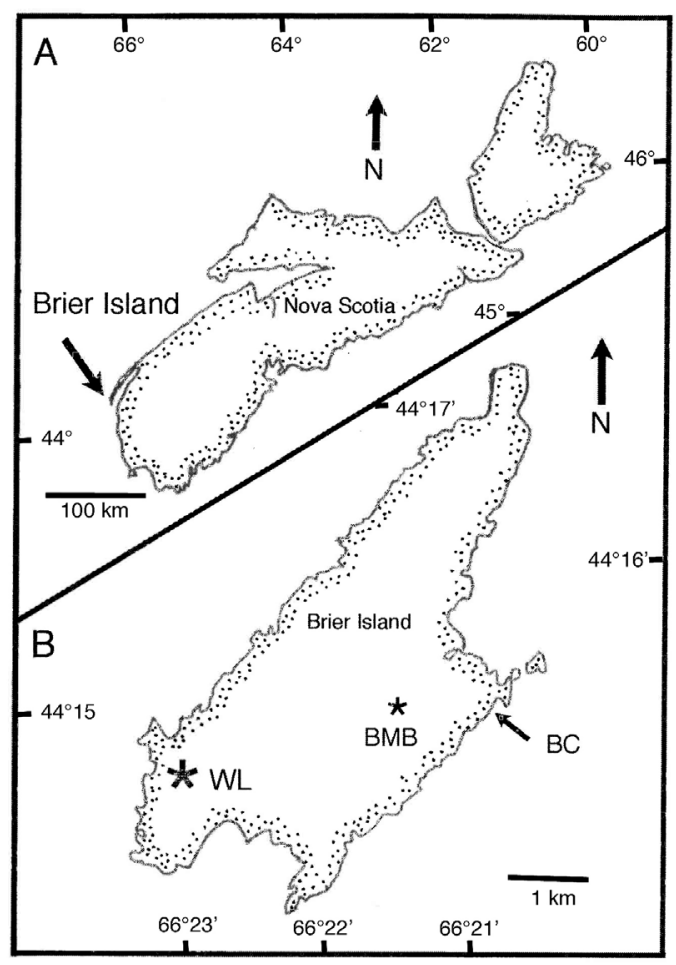

Fig 1 Map of Nova Scotia (A) with insert of Brier Island (B) indicating breeding colonies of Herring Gulls in Big Meadow Bog (BMB), Big Cove (BC) and Western Light (WL), the latter where Prasiola crispa was found.

habitat in early to mid-August 2016. The individual rock outcrops ranged from ca. $1 \mathrm{~m}^{2}$ to about $100 \mathrm{~m}^{2}$, and many had patches of lichens, mosses and heath plants. The position of each outcrop with evident gull feces was recorded as degrees, minutes and decimal minutes to three decimal places using a hand-held GPS unit (Garmin eTrex, Olathe, Kansas), along with the occurrence of populations of Prasiola. The position of each of these outcrops was later mapped onto Google Earth (Fig 2).

The microhabitat of the colonies on the outcrops (i.e., flat surface, crevices, slope and shade from surrounding vegetation) and aspect (i.e., general direction of the primary colonies) were also noted. On each outcrop where Prasiola occurred, a numbered sample from the largest one or two patches was scraped into separate plastic bags that were returned to the laboratory for microscopic evaluation. 


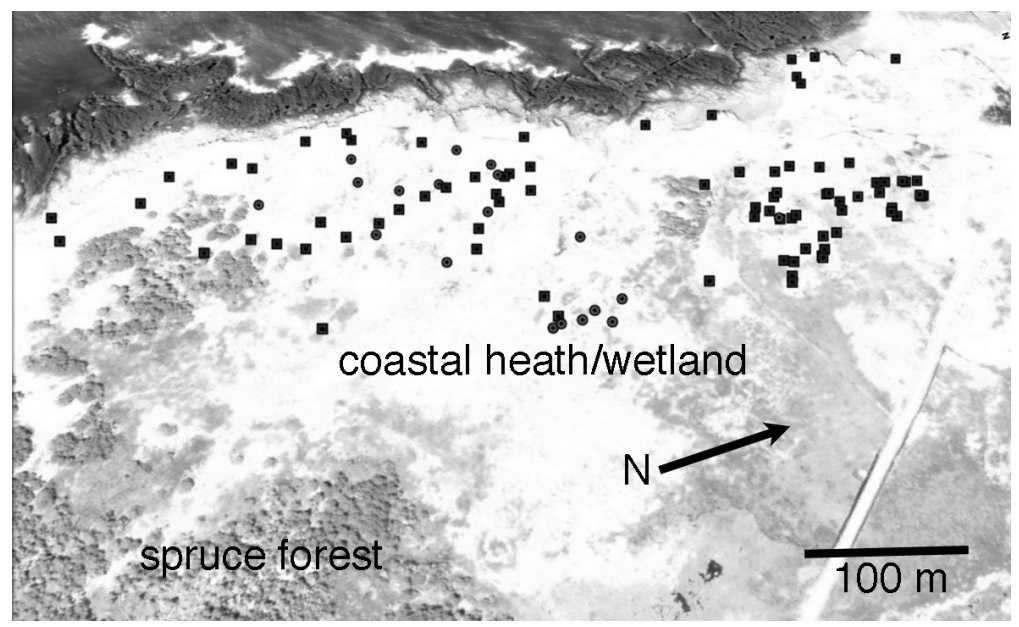

Fig 2 Google Earth image of habitat at Western Light on Brier Island indicating distribution of rock outcrops with gull droppings, either with (circles) or without (squares) colonies of Prasiola crispa.

Microscope slides were made from each collection, and identification was based on the key in Rindi (2007). Herbarium specimens were deposited in STFX, ACAD and MICH.

\section{RESULTS}

Microscopic examination of the collected samples from Western Light showed that only Prasiola crispa was present (Fig 3). Two additional collections from the splash zone at Northern Light were P. stipitata.Prasiola crispa is morphologically distinct from the other terrestrial species of the genus in lacking a conspicuous stipe. The colonies on each outcrop consisted of thousands of overlapping fronds no more than $3 \mathrm{~mm}$ high. The filamentous form of this species (Rindi 2007) was observed on slides made from thalli of several of the 19 outcrops. These short uniseriate filaments can develop into the multiseriate monostromatic blades typical of the species (Rindi 2007). Some fronds had masses of spore-like structures (akinetes) formed by the apparent dissolution of the parental fronds.

One hundred and two separate outcrops (Fig 2) with gull dropping were sampled on the three random walks. Several additional outcrops near the northern end of the Western Light colony at the road had 


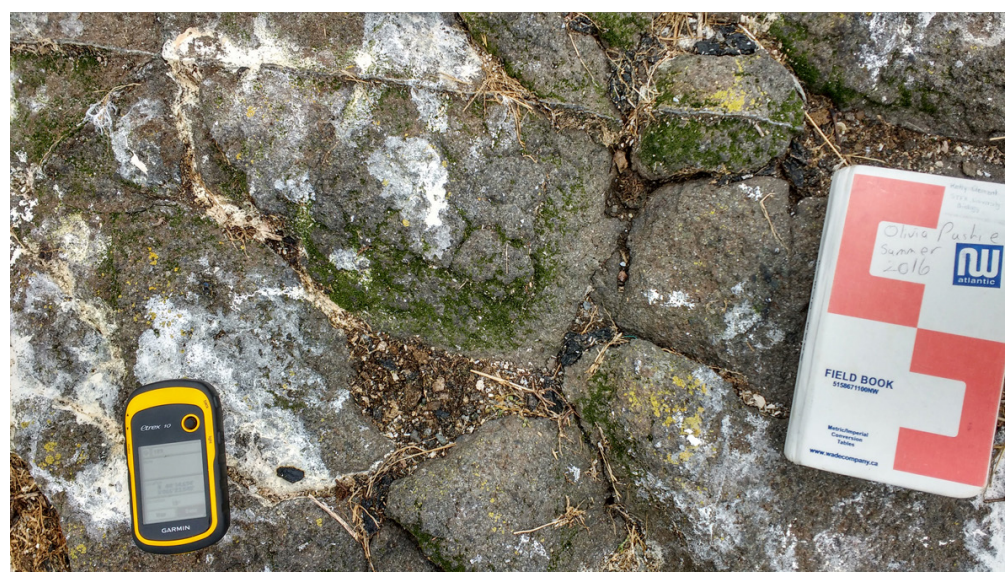

Fig 3 Portion of rock surface with typical patches of Prasiola crispa (green) and extensive gull droppings (white). Field book and GPS for scale.

neither droppings nor P.crispa. Of the 102 outcrops with gull droppings, P. crispa was present on $19(18.6 \%)$. On some outcrops, there was a single well-defined patch from $10-50 \mathrm{~cm}^{2}$, whereas on other outcrops, there were many small to large irregular-shaped patches (Fig 3). Colonies were rare on the flat upper surface of the rock, fully exposed to the sun. Most colonies were on the sloped sides of the outcrops and many were north facing. Some patches were in depressions in the rock or shaded by adjacent shrubs or boulders.

Prasiola crispa was not randomly dispersed. No apparent colonies were seen close to the road, and none on the cliff tops adjacent to the shore. Indeed, $20 \mathrm{~m}$ was the closest that $P$. crispa was found to the seashore cliff tops (ca. $5 \mathrm{~m}$ above high tide). The furthest from the shore that we found P. crispa was about $150 \mathrm{~m}$. Prasiola crispa was most frequent in the central nesting area of Western Light where many outcrops stood out above the surrounding vegetation and allowed the birds vantage points and access to nest sites in the surrounding vegetation.

A search of other gull nesting sites on Brier Island was carried out. The Herring Gull nesting population on the cliff side in the eastern corner of the island (near Big Cove) with extensive basalt columns has a south facing exposure and the spruce forest comes to the top of the cliff, thereby restricting habitat for Prasiola. Exploration of this area revealed no Prasiola. Two populations of $P$. stipitata were confirmed near Northern Light in the splash zone, one of 
these being used for the physiological study by Kang et al. (2013). Nesting colonies of various seabirds are also present on Peters Island (Stewart et al.2015) but access to survey for Prasiola was not possible.

\section{DISCUSSION}

This survey of Prasiola crispa on Brier Island provides an indication of its preferred habitat in Nova Scotia. The microhabitat distribution of $P$. crispa over the 102 sampled outcrops shows that it is primarily associated with shaded or north- facing rock surfaces, as well as depressions and crevices. The association with high nutrient loading was confirmed as rocks without droppings never had P. crispa. We did not attempt to quantify the abundance of fecal deposits in relation to the abundance of the P.crispa, but the general distribution of the alga in the area where the gulls, and their droppings, seemed most abundant, would suggest significant levels of droppings are required for the alga to thrive. However, the abundance of $P$. crispa may simply reflect gull activity, and possible gull dispersal, rather than amount of nutrients per se. The relationship with sea spray commented upon by most authors (e.g., Rindi 2007) was not observed; indeed P. crispa was not found at the top of the sea cliffs that lined the shore at Western Light, despite the abundance of gulls and their droppings.

The influx of Herring gulls to Brier Island began in the 1970s and led to the formation of the large nesting colony in Big Meadow Bog. The natural landscape near Western Light of rock outcrops in a wetland/coastal heath plant community, combined with human intervention, gave rise to a partially dried wetland that attracted a portion of the nesting Herring gull population that increased until at least 2006 (Eric Mills, personal communication). The outcrops on Brier Island provide perching vantage points, and the vegetation provides suitable nest building sites that are hidden from predators. As a result of breeding activity, the gulls have acted as ecological engineers from two perspectives: 1) the nutrient loading and trampling modified the plant community (Hill, unpublished observations), and 2 ) the gull droppings provided the habitat for P. crispa. Based on the $19 \%$ current colonization by P. crispa of the available rock outcrops, we suggest that $P$. crispa likely arrived following the increase in the Herring gull population on the island. Without long-term 
observation, experimental manipulation and molecular fingerprinting, it is difficult to know whether wind based or gull based dispersal of P. crispa occurs within the habitat or over larger geographic distances. However, adult and juvenile movement on and around the outcrops likely facilitates the transport of algal propagules; during parental feeding of the chicks via regurgitation pellets or the smashing of larger food items on the rocks (e.g. crabs, sea urchins, molluscs), spores or small frond may be dispersed.

Unlike other Prasiola species, the occurrence of P. crispa may be more closely associated with seabird areas (Broady, 1996). P. crispa has been identified in the nesting material and as gull-transported materials in Antarctica (Parnikoza et al., 2012). Wind may also be a dispersal agent of the microscopic spores and juvenile fronds as suggested for the supratidal Prasiola species by Garbary \& Tarakhovskaya (2013) on the shores of the White Sea.

Herring Gull colonies are numerous along the Atlantic coast of Nova Scotia (Chardine 2015). Some gulls have been tracked from Kent Island to Brier Island (Shlepr 2017), both being boreal outposts in the Bay of Fundy. As several boreal plants occur on Brier Island (Hill and Garbary, unpublished) and two-thirds of the moss flora of Kent Island is boreal (Futamura and Wheelwright 2000), we predict that the epilithic boreal alga, P. crispa, could be more widely dispersed on seashore gull colonies around the Bay of Fundy where boreal conditions occur. Further surveys should be done, and P. crispa may be useful as a biomonitor to study the impact of the Gulf of Maine warming that has been recently documented (Pershing et al. 2015).

Acknowledgements We thank Michael Wynne for providing samples of historical herbarium specimens at MICH of Prasiola crispa from Newfoundland. This work was funded by grants from the Natural Sciences and Engineering Research Council of Canada to DJG. Funding from Environment Canada for the Big Meadow Bog Restoration project facilitated this work. 


\section{REFERENCES}

Blaney,S.C. (2010). COSEWIC assessment and status report on the Eastern Mountain Avens, Geum peckii, in Canada. Committee on the Status of Endangered Wildlife in Canada, Ottawa. (www.sararegistry.gc.ca/status/ status_e.cfm).

Broady, P.A. (1996). The distribution of Prasiola calophyla (Carmich.) Menegn. (Chlorophyta) in Antarctic freshwater and terrestrial habitats. Antarctic Science 1:109-118.

Brown, R.G.B. \& Gaskin, D.E. (1988). The pelagic ecology of the Grey and Red-necked Phalaropes Phalaropus fulicarius and P. lobatus in the Bay of Fundy, eastern Canada. Ibis 130:234-250.

Chardine, J. (2015). Herring Gull. In: Stewart, R.L.M., Bredin, K.A., Couturier, A.R., Horn, A.G., Lepage, D., Makepeace, S., Taylor, P.D., Villard, M.-A., \& Whittam, R.M. (eds.), Second Atlas of Breeding Birds of the Maritime Provinces. Bird Studies Canada, Natural History Society of Prince Edward Island, Nature New Brunswick, New Brunswick Department of Natural Resources, Nova Scotia Bird Society, Nova Scotia Department of Natural Resources, Prince Edward Island Department of Agriculture and Forestry, Sackville, pp. 232-233.

Collins, F.S. (1909). The green algae of North America. Tufts College Studies 2:79-480 + plates I-XVIII.

Cotter, R.C., Rail, J.F., Boyne, A.W., Robertson, G.J., Weseloh, D.V.C., \& Chaulk, K.G. (2012). Population status, distribution, and trends of gulls and kittiwakes breeding in eastern Canada, 1998-2007. Canadian Wildlife Service Occasional Paper No. 120, Ottawa, Ontario, 96 pp.

Davis, D.S., \& Browne, S. (1997). The Natural History of Nova Scotia. Volume One, Topics and Habitats. Nimbus, Nova Scotia Museum, Halifax.

Edelstein, T., Chen, L., \& McLachlan, J. (1969). Investigations of the marine algae of Nova Scotia. VIII. The flora of Digby Neck Peninsula, Bay of Fundy. Canadian Journal of Botany 48:621-629.

Futamara, C.W. \& Wheelwright, N.T. (2000). The mosses of Kent Island, New Brunswick. Northeastern Naturalist 7:277-288.

Garbary, D.J. (2007). The margin of the sea: life at the top of the tides. In: Seckbach, J. (ed.), Algae and Cyanobacteria in Extreme Environments. Springer, Berlin, pp. 173-191.

Garbary, D.J., \& Hill, N.M. (2014). A disjunct, sea-level population of a globally rare Avens keeps its mountain manner. Botany 92:657 (abstract only).

Garbary, D.J., \& Tarakhovskaya, E.R. (2013). Marine macroalgae and associated flowering plants from the Keret Archipelago, White Sea, Russia. Algae 28:267-280.

Gauthier B., Cardinal, A. \& Himmelman, J.H. (1980). Limites amont de distribution des algues marines benthiques dans l'estuaire du SaintLaurent (Québec), et addition de quelques èspeces á la flore de cette region. Naturaliste Canadien 107:67-86. 
Guiry, M.D. (2016). In Guiry, M.D., \& Guiry, G.M. AlgaeBase. Worldwide electronic Publication, National University of Ireland, Galway, algaebase.org; searched on 18 January 2017.

Kang, E.U., Scrosati, R., \& Garbary, D.J. (2013). Physiological ecology of Prasiola stipitata (Trebouxiophyceae) from the Bay of Fundy, Canada. Phycological Research 61:208-216.

Mathieson,A.T., \& Dawes, C. (2017). Seaweeds of the Northwest Atlantic. University of Massachusetts Press, Amherst, MA (in press).

Parnikoza, I., Dykyy, I., \& Ivanet, V. et al. (2012). Use of Deschampsia Antarctica for nest building by the kelp gull in the Argentine Islands (Maritime Antarctica) and its possible role in plant dispersal. Polar Biology 35:1753-1757.

Paterson, I.G., \& Snyder, M. (1999). Genetic evidence supporting the taxonomy of Geum peckii (Rosaceae) and G. radiatum as separate species. Rhodora 101:325-340.

Pershing, A.J. , Alexander, M.A., Hernandez, C.M., Kerr, L.A., Le Bris, A., Mills, K.E., Nye, J.A., Record, N.R., Scannell, H.A., Scott, J.D., Sherwood, G.D., \& Thomass, A.C. (2015). Slow adaptation in the face of rapid warming leads to collapse of the Gulf of Maine cod fishery. Science 350:809-812.

Rindi F. (2007). Prasiolales. In: Brodie, J., Maggs, C.A. \& Dring, D.M. (eds.), Green Seaweeds of Britain and Ireland. British Phycological Society, Dunmurry, Northern Ireland, pp. 13-31.

Sears, J.R. [ed.] (1998). NEAS Keys to the Benthic Marine Algae of the Northeastern Coast of North America from Long Island Sound to the Strait of Belle Isle. Northeast Algal Society, Contribution Number 1.

Shlepr, K. (2017). The geography of diet: diversity in diet and foraging behavior in Herring Gulls across Atlantic Canada. MSc Thesis, University New Brunswick, Fredericton.

South,G.R.(1973).Algae Terrae Novae, exsiccata of Newfoundland benthic marine algae. Taxon 22:451-454.

South, G.R, Tittley, I., Farnham, W.F., \& Keats, D.W. (1988). A survey of the benthic marine algae of southwestern New Brunswick, Canada. Rhodora 90:419-451.

Stewart, R.L.M., Bredin, K.A., Couturier, A.R., Horn, A.G., Lepage, D., Makepeace, S., Taylor, P.D., Villard, M.-A., \& Whittam, R.M. [eds.] (2015). Second Atlas of Breeding Birds of the Maritime Provinces. Bird Studies Canada, Natural History Society of Prince Edward Island, Nature New Brunswick, New Brunswick Department of Natural Resources, Nova Scotia Bird Society, Nova Scotia Department of Natural Resources, Prince Edward Island Department of Agriculture and Forestry, Sackville.

Taylor, W.R. (1957). Marine Algae of the Northeastern Coast of North America. University of Michigan Press, Ann Arbor, Michigan.

Tomassen, H.B.M., Smolders, A.J.P., Lamers, L.P.M., \& Roelofs, J.G.M. (2005). How bird droppings can affect the vegetation composition of ombrotrophic bogs. Canadian Journal of Botany 83:1046-1056. 
Toms, B. (2015). Eastern Mountain Avens - Implementation of High Priority Recovery Actions: Habitat management and implications for Herring Gull monitoring at Brier Island, NS. Report to Canadian Wildlife Service. Wilson, J.S., Bird, C.J., McLachlan, J., \& Taylor, A.R.A. (1979). An annotated checklist and distribution of benthic marine algae of the Bay of Fundy. Memorial University of Newfoundland, Occasional Papers in Biology 2:1-65. 
